\title{
st \\ Filosofia e medicina em La Mettrie
}

\author{
Marisa Carneiro de Oliveira Franco Donatelli

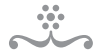 \\ RESUMO
}

Para La Mettrie, o estudo da natureza inicia-se no homem cuja estrutura deve ser considerada em comparação com a dos animais, estando todos submetidos às mesmas leis e sujeitos à destruição. Ao adotar o ponto de vista médico, La Mettrie aproxima a filosofia da medicina. A partir dessa aproximação, o presente trabalho tem por objetivo abordar como se dá a vinculação entre medicina e filosofia, enfatizando o entrelaçamento entre os pontos de vista médico, filosófico e moral.

PaLAVRaS-GhaVe • Materialismo. Organização. Remorso. Moral da natureza.

\section{INTRODUÇÃO}

Logo no início do Tratado da alma, La Mettrie deixa bem claro que não se preocupará com a busca das essências da alma e do corpo, uma vez que tal conhecimento é impossível, já indicando a inutilidade desses estudos, a qual será reafirmada no Discurso preliminar. O conhecimento possível das propriedades da alma está pautado naquelas que se manifestam no corpo, tomando como guia os sentidos, pois só eles podem nos levar ao conhecimento da verdade (cf. La Mettrie, $1987 \mathrm{c}, \mathrm{p} .125$ ). O organismo torna-se o centro da reflexão lamettriana, tendo como apoio as leis mecânicas que regem as funções do corpo do ser vivo. Considerar o homem em todas as suas idades e em todos os seus estados é a recomendação básica defendida por La Mettrie para construir uma filosofia que seja consequente e que se afaste dos devaneios engendrados pela pretensão metafísica ao se voltar para o conhecimento de objetos inacessíveis, tal como se mostra a questão concernente à natureza da alma. É assim que o homem se torna o foco principal de seus estudos, mas de uma forma muito específica. Ele se torna o modelo físico e intelectual do universo, como afirma Vartanian, de forma que esse universo fica reduzido à máquina. Mas há uma contrapartida, pois a própria natureza se humaniza ao estabelecer-se essa comparação com o homem "mecanizado" (cf. Vartanian, 1999, p. 54). Além disso, o homem, ao se tornar a referência central, serve de medida para o que existe ao seu redor, o mundo se torna a sua imagem. 
Neste artigo, abordaremos, a partir de alguns textos filosóficos de La Mettrie, ${ }^{\mathbf{a}}$ a adoção da medicina como diretriz para sua reflexão filosófica e seus aspectos moralizantes, que sofreram alterações ao longo do desenvolvimento de seu pensamento, sempre tendo como pano de fundo o combate, por parte do autor, às hipóteses abstratas que estão na base da construção dos sistemas metafísicos. Se é verdade que nos estudos mais referidos de Anne Thomson (1981) e de Aram Vartanian (1960) encontramos a afirmação da relação muito estreita entre o projeto filosófico empreendido por La Mettrie e a medicina, no entanto, ela não se apresenta com destaque no que diz respeito aos aspectos moralizantes de sua reflexão filosófica. Vartanian faz referência à "filosofia biológica” e à "psicologia fisiológica" (Vartanian, 1960, p. 45), enquanto Thomson ${ }^{2}$ afirma que, pelo menos em parte, o ponto de vista médico deve ser considerado na abordagem dos textos de La Mettrie (cf. Thomson, 1981, p. 48-9), ao mesmo tempo que defende a prática e o conhecimento médicos (p.56,64) como componentes da base de seu materialismo, bem como das teorias psicológica e moral. Claude Morilhat (1997), por sua vez, afirma que "a medicina conduziu La Mettrie à filosofia através do reconhecimento do papel determinante da máquina corporal para a totalidade do comportamento humano, seja na relação do indivíduo com a natureza, seja nas relações sociais" (Morilhat, 1997, p. 14). Não obstante o reconhecimento da importância da medicina na constituição da filosofia de La Mettrie, que é abordada na terceira parte do referido trabalho, ela fica eclipsada no capítulo dedicado à ética, ainda que contenha algumas passagens que remetam à fisiologia (cf. Morilhat, 1997, p. 91-121). Um texto recente, que trata especificamente da moral em La Mettrie, La réduction médicale de la morale chez La Mettrie, é o de Charles Wolfe (cf. Audidière, 2006, p. 45-6o), que defende essa redução como uma medicalização da moral e a inseparabilidade entre a moral defendida por La Mettrie e "sua concepção de homem-máquina”. Apesar do objetivo declarado de delimitar a maneira pela qual La Mettrie "transforma a moral em um problema médico", ao longo de seu trabalho podem ser detectados pelo menos dois pontos que comprometem esse encaminhamento. Em primeiro lugar, o propósito indicado pelo autor acaba por ficar prejudicado por não respeitar a cronologia das obras

1 Evitamos buscar uma paternidade filosófica para La Mettrie, tarefa que, além de poder levar a simplificações grosseiras, mostra-se de pouco proveito, uma vez que as referências em seus textos a outros filósofos são abundantes e variáveis: Epicuro, Locke, Leibniz, Spinoza, Descartes, entre outros, são referidos em suas obras, mas nem sempre com o mesmo propósito. Para nos atermos às obras aqui mencionadas, seguem dois exemplos: Descartes, no Homemmáquina, é mencionado como aquele que possibilitou sua interpretação materialista do homem, mas no Tratado da alma , a rejeição ao filósofo aparece logo no início e permanece em vários capítulos no que diz respeito às concepções de alma e de matéria; Leibniz aparece nesse mesmo texto como próximo de La Mettrie quanto à atividade da matéria, mas, no Homem-máquina, esse filósofo é rejeitado com toda a crítica à metafísica.

2 Particularmente os capítulos 3 e 4 da introdução ao Discurso preliminar (cf. Thomson, 1981, p. 33-77). Merece destaque o capítulo 2 voltado para a importância dos trabalhos médicos de La Mettrie para a constituição de seu materialismo (p. 21-32). 
ali analisadas, que possibilitaria vislumbrar o desenvolvimento do pensamento lamettriano. Além disso, um ponto importante nesse encaminhamento proposto por Wolfe refere-se ao conceito de remorso e à transformação pela qual ele passa. É verdade que o autor o menciona, porém não há qualquer desenvolvimento que torne mais claro como La Mettrie concebe o sentimento de remorso e a transformação pela qual essa concepção passa, na construção da moral (cf. Audidière, 2006, p. 55), como se pretende mostrar ao longo deste trabalho.

Considerando essas observações, este artigo segue a orientação dos trabalhos de Thomson e Vartanian, mas, ao explicitar a relação de proximidade mencionada acima, adota uma ordenação cronológica dos textos selecionados, com o objetivo de mostrar o desenvolvimento do pensamento lamettriano no que diz respeito ao vínculo que se estabelece entre a moral e a física. Nesta abordagem, não podemos deixar de considerar as datas de publicação dos primeiros textos filosóficos de La Mettrie, que remetem à precedência das publicações referentes à medicina. A importância dessa consideração situa-se no fato de encontrarmos nos textos médicos os indícios do materialismo com o qual La Mettrie teve contato, quando ingressou no círculo de Boerhaave. ${ }^{3}$ Materialismo este que ganhará um enfoque preciso ao longo do desenvolvimento de seu pensamento. $\mathrm{O}$ objetivo da integração a esse círculo está ligado à divulgação, na França, do método boerhaaviano, pautado na observação e na experiência. A importância desse método na obra de La Mettrie é de tal monta que se costuma afirmar que a conclusão à qual chegou, de que o pensamento é resultado da organização da máquina corpórea, foi reforçada pela observação de desregramentos sanguíneos em seu próprio corpo, quando, em 1744, foi acometido por uma violenta febre e, antes disso, por suas observações sobre a epidemia de cólera em 1741/42, na Bretanha, nas quais enfatiza a influência dos estados corpóreos sobre os da mente (cf. Lange, 2004, p. 294; Thomson, 1981, cap. 1, 2; Vartanian, 1960, p. 40). Mas, antes dessas datas, o Tratado sobre a vertigem, publicado em 1738, mostra a tendência de La Mettrie para adotar essa forma de

3 Durante sua estadia em Leyden, de 1733 a 1734 , La Mettrie adere à medicina ensinada por Herman Boerhaave (1668-1738), para quem os fenômenos orgânicos devem ser compreendidos a partir da consideração de leis físicas e da hidráulica que os sustentam. Com Boerhaave, a experiência sensível ganha destaque ao enfatizar o valor dos efeitos observáveis dos corpos e ao descartar a possibilidade de se conhecer a sua natureza. O método por ele adotado enfatiza a importância de se estudar Hipócrates, da mecânica dos sólidos e dos fluidos, para a compreensão dos mecanismos que conservam a vida, e a defesa de que no corpo tudo pode ser explicado por meio das leis da mecânica. Em Boerhaave encontra-se a combinação entre a experiência e o raciocínio; se não podemos conhecer as causas, devemos ter como ponto de partida a experiência e, por meio do raciocínio geométrico, podemos estender os resultados da observação. Mas a garantia de certeza está assentada na experiência. Esses pontos característicos da medicina boerhaaviana estão bem presentes em La Mettrie, que estudou com muito cuidado a obra desse médico, chegando a traduzir vários de seus textos. Dentre esses textos, Jacques Richard destaca a segunda edição das Instituições médicas, com a qual ele compara alguns trechos do texto original de Boerhaave, de 1708, com a finalidade de mostrar a liberdade de La Mettrie ao inserir suas reflexões no texto original (cf. Richard apud Audidière, 2006, p. 24-8). 
pensamento, quando se volta para questões que envolvem a relação corpo e alma. Esse tratado - com forte influência do mecanicismo de Herman Boerhaave, a quem o tratado é dedicado -, uma vez que todos os desajustes que ocorrem no corpo recebem explicação mecânica, compõe um dos volumes de suas obras filosóficas e mostra-se como um sintoma da estreita união entre a medicina e a filosofia que ganhará vulto no decorrer do tempo. Afinal, no Tratado sobre a vertigem, pode-se observar a defesa da relação corpo e alma por meio da explicação adotada para a compreensão dessa patologia que está intimamente ligada às ilusões que os sentidos nos oferecem, quando há algum desarranjo orgânico, e alterações nos músculos. Segundo a explicação anatômica contida no tratado, a retina é um prolongamento da medula do nervo ótico e, quando este sofre alguma perturbação, esta repercutirá na retina e a vertigem ocorrerá. O desarranjo das fibras óticas provoca alteração nos ângulos que os raios de luz formam com elas, dando origem à vertigem. Assim, um "movimento aparente de um objeto imóvel depende do menor desarranjo das fibras da retina ou do nervo ótico" (La Mettrie, 1987a, p. 20).

Nesse texto, já se nota que, a partir de seu conhecimento de anatomia, La Mettrie procura lançar uma explicação sobre as faculdades da mente. É nesse contexto explicativo que surge a História natural da alma (publicada anonimamente em 1745), depois republicada, com alguns cortes, sob o título Tratado da alma e que deu início à construção da história natural do homem. 4 A alteração do título de história para tratado pode ser atribuída à estrutura pouco de acordo com o que se costuma vincular à história natural. Afinal, esse texto mais se aproxima de um tratado metafísico, ${ }^{5}$ uma vez que não coloca em relevo um método que se paute na observação e que se apresente suficientemente empírico para a designação de "história natural”.

\section{Tratado da alma E A INTERPRETAÇÃO MATERIALISTA}

O Tratado da alma contém uma estrutura que mostra a prevalência de tudo o que remete ao corpóreo. A obra inicia-se com uma reflexão sobre a matéria, incluindo suas propriedades mecânicas, passando pela potência motriz até chegar ao ponto referente às sensações, que tomamos como central. Nesse ponto - sensações - estão presentes

\footnotetext{
4. O Tratado da alma será o texto aqui utilizado. Trata-se da versão final da História natural da alma que foi publicada na primeira edição das Euvres philosophiques de La Mettrie (cf. Thomson, 1981, p. 35). A história natural do homem é composta pelas seguintes obras: Histoire de l'âme, L'homme-machine, L'homme-plante, Les animaux plus que machines e Système d'Épicure.

$5 \mathrm{O}$ empréstimo feito à metafísica aristotélica e escolástica o indicam. $\mathrm{O}$ recurso às formas substanciais no capítulo 7 dessa obra será alvo de crítica pelo próprio autor em sua obra mais conhecida, O homem-máquina, de 1747. A distinção escolástica entre alma vegetativa, sensitiva e intelectiva também está presente nessa obra.
} 
as referências à alma, enquanto vinculada à matéria, como sedes da alma, extensão da alma, vinculação entre ser sensitivo e ser material, dependência de faculdades em relação aos órgãos sensíveis, culminando com a seguinte afirmação:

nada sabemos além daquilo que as sensações nos ensinam (...); e por consequência não devemos nos permitir formar, para além delas, qualquer espécie de conjectura (La Mettrie, 1987b, p. 207).

Nesse texto, a organização do corpo ainda não aparece como ponto central de suas reflexões, mas todas as operações da mente são expostas sob o ponto de vista físico. Ao adotar a distinção escolástica entre almas, o autor coloca toda a ênfase na alma sensitiva, ${ }^{6}$ de maneira a destacar a dependência das operações intelectivas em relação aos sentidos e, com isso, eliminar qualquer referência à alma imaterial. La Mettrie parte do pressuposto da impossibilidade de se conhecer a essência da alma, assim como a da matéria e dos corpos, e defende que a alma separada do corpo por abstração corresponde à matéria considerada sem qualquer forma, o que, para ele, vem a ser inconcebível; eles estão juntos desde sempre. A matéria é uma de suas propriedades, conforme consta no Tratado da alma, o poder de receber diferentes formas. Por elas, como afirma o autor, a matéria "pode adquirir a força motriz e a faculdade de sentir" (La Mettrie, 1987c, p. 127). Essa afirmação reveste-se de importância para a compreensão do desenvolvimento do pensamento de La Mettrie, pois aí se situa a crítica à redução da essência da matéria à extensão, defendida por Descartes. A extensão, para La Mettrie, é uma propriedade da matéria que só podemos conhecer por meio dos sentidos, ou seja, pela percepção da altura, da largura e da profundidade. As propriedades da extensão são mecânico-passivas. Em outras palavras, podemos afirmar que a extensão vincula-se às formas passivas que sempre estão presentes na matéria, como a grandeza, a figura, o repouso e a situação. A matéria, considerada em sua extensão, é princípio passivo. Mas ela só pode receber essas formas passivas por meio de sua força motriz. Como a determinação de uma forma em detrimento de outra só é possível por meio de uma atividade, isso significa que a natureza da matéria não pode ser totalmente inerte,

6 Esta obra tem forte influência do médico Guillaume Lamy (1644-1683), que é várias vezes referido. Lamy, ao colocar o movimento da matéria como base de sua explicação do homem, tanto do ponto vista físico como do mental, segue a tradição do atomismo epicurista. Além disso, ele adota procedimentos cuja defesa encontramos nas obras de La Mettrie: comparação entre as estruturas do homem e dos animais; explicação mecânica referente à "alma sensitiva" que fica atrelada às sensações externas e internas do corpo e está presente nos homens e nos animais; explicações fundadas na observação da estrutura do corpo. Explicações essas que compõem os seus Discursos anatômicos, cuja primeira edição é de 1675 , e a sua Explicação mecânica e física das funções da alma sensitiva, ou dos sentidos, das paixões e do movimento voluntário, com primeira edição em 1677, obra esta escrita como uma resposta às críticas que os Discursos sofreram. 
mas dotada de uma forma fundamental que é a forma ativa, ou seja, a forma pela qual a matéria produz aquelas outras formas que ela recebe. Assim, se a substância dos corpos, isto é, a matéria, tem a capacidade de se mover por si mesma, não há necessidade de se conceber um agente externo a ela como causa de seu movimento. Esse agente se reduz a um "ser de razão", pois há uma força intrínseca na substância dos corpos, a saber, a ação das partes da substância é a causa do surgimento das formas "pelas quais a força motriz dos corpos se torna efetivamente ativa" (La Mettrie, 1987c, p. 137) e ela é suficiente para engendrar as leis do movimento: "é assaz evidente que a matéria contém essa força motriz que a anima e que é a causa imediata de todas as leis do movimento" (p. 138).

É dessa maneira que se inscreve a crítica de La Mettrie à concepção passiva da matéria defendida pelos cartesianos, pois ela é pouco exata e fruto da má compreensão do conceito.

Além das duas propriedades da matéria já afirmadas, La Mettrie defende uma terceira, a faculdade de sentir. Esse ponto é relevante, pois, ao atribuir à matéria a capacidade de sentir, as bases para a concepção materialista de homem começam a ser constituídas. A partir da recusa em aceitar a concepção cartesiana de matéria, que tem por consequência a afirmação da insensibilidade dos animais, La Mettrie, na defesa da existência desse terceiro atributo na matéria, vai se valer da anatomia comparada para fundamentar a sua oposição a Descartes. Segundo La Mettrie, a faculdade de sentir está presente apenas na matéria organizada, ou seja, está presente nos seres vivos, e não se encontra em outra substância que não seja a matéria aí presente e, por isso, não há necessidade de se recorrer a qualquer outra substância para explicar as sensações externas e internas, como o fazem aqueles que seguem os passos de Descartes. Afinal, a faculdade de sentir é observada nos corpos, mas apenas nos corpos organizados, por isso não se pode afirmar com fundamento que a matéria tenha em si a faculdade de sentir ou que ela possa ser adquirida por meio de modificações ou por meio de formas às quais é suscetível. Por essa razão, essa faculdade fica designada como residindo em potência na matéria, da mesma forma como a capacidade de se mover, acima mencionada. A matéria, então, segundo a concepção lamettriana, é extensa, móvel, tem a potência de se mover por si mesma, e é suscetível de sensação e de sentimento (cf. La Mettrie, 1987c, p. 143).

Vamos ater-nos à faculdade sensitiva da matéria, pois ela se apresenta como central para a nossa abordagem, uma vez que as operações da mente passarão pelo seu crivo, indicando o ponto de vista médico adotado por La Mettrie em questões referentes à filosofia. A alma sensitiva, caracterizada como um princípio material voltado para o sentir, discernir e conhecer nos seres vivos, é constituída por um sistema formado pelo cérebro, que concentra as sensações, pelos nervos que as conduzem, e pelos ór- 
gãos dos sentidos que registram as sensações. Nesse esquema interpretativo das sensações, os espíritos animais estão presentes, como é comum nas explicações sobre o processo das sensações. ${ }^{7} \mathrm{Na}$ explicação do mecanismo da sensação, La Mettrie afirma que o final do processo se dá no sensorium commune, identificado como a sede da alma sensitiva, e considera o refluxo dos espíritos animais nessa etapa final da percepção sensível que age sobre a alma sensitiva. As terminações dos nervos localizam-se no sensorium commune situado no cérebro, por meio das quais são estabelecidas as ligações com todos os órgãos dos sentidos. Nesse quadro da descrição do ambiente em que se dão as sensações, La Mettrie destaca a submissão ou dependência, chamemos assim, da alma (mantendo a denominação "alma sensitiva") em relação aos estados do corpo, com base em experiências que remetem aos estudos de Galeno sobre o cérebro e sobre a secção dos nervos. É assim que

quando essa parte [o cérebro] é ferida de forma considerável, o animal não mais tem sensação, discernimento ou conhecimento. Todas as partes que estão acima das feridas e da ligadura conservam, entre elas e o cérebro, o movimento e a sensação perdidos abaixo, entre a ligadura e a extremidade (La Mettrie, 1987c, p. $\left.15^{2}\right)$.

Tal experiência confirma que a alma é afetada pelas sensações no cérebro e, se houver algum desarranjo em qualquer parte do corpo, isso repercutirá, alterando a percepção e levando a alterações de comportamento e das próprias sensações, como ocorre no caso da vertigem (cf. La Mettrie, 1987b, p. 22). Nessa exposição, o legado de Thomas Willis ${ }^{\mathbf{8}}$ mostra-se claramente contra os que defendem que a alma sente por todo o corpo, uma vez que a enervação está presente em sua totalidade. 9 Ora, a secção de um membro não elimina a sensação que ainda permanece, mesmo que o membro não mais exista, o que é confirmado pela experiência. Isso indica que a alma não sente nos órgãos afetados, a sua sede é extensa, pois ela está espalhada por todo o cérebro, de onde os nervos se originam. A consideração do refluxo dos espíritos animais, ainda que apenas mencionada, vincula-se à explicação da percepção dos objetos externos

7 Como pode ser constatado em Hobbes, em Descartes e em Locke. Este último muito presente em La Mettrie, no que se refere à formação das ideias.

8 Thomas Willis (1621-1675) vincula-se ao epicurismo recuperado por Gassendi no século xviI combinado com a iatroquímica. Dentre seus trabalhos sobre a anatomia e funcionamento do cérebro destacam-se Cerebri anatome: cui accessit nervorum descriptio et usus, de 1664, e De anima brutorum quæ hominis vitalis ac sensitiva est, excertitationes duæ; prior physiologica ejusdem naturam, partes, potentias et affectiones tradit; altera pathologica morbos qui ipsam, et sedem ejus primarium, nempe ceerebrum et nervosum genus atticiunt, explicat, eorumque therapeias instituit, de 1672 . 9 La Mettrie se refere aos estóicos, na Antiguidade, e a Claude Perrault (Mécanique des animaux, 1680-1688), entre outros modernos (cf. La Mettrie, $19^{8}$ ? b, p. $15^{3}$ ). 
em Willis, segundo a qual, os objetos, ao afetarem os órgãos dos sentidos, geram impressões que são transportadas pelos espíritos animais para o sensorium commune, sediado nos corpos estriados e que, ao passarem pelo corpo caloso até o córtex cerebral, dão origem a uma percepção. Os espíritos são produzidos no córtex e no cerebelo de onde se espalham por outras partes do cérebro e aí permanecem até a ocorrência de algum evento que provoque seu movimento em ondas, conduzindo-os à parte afetada e, desta, para o cérebro, considerando que uma parte dos espíritos animais está espalhada pelo corpo, estruturando os órgãos dos sentidos, além dos que servem ao movimento.

Para compreendermos melhor essa dependência entre os estados do corpo e as faculdades da mente convém considerar a abrangência da alma sensitiva, a saber, as sensações, a memória, a imaginação, as paixões, a vontade, o discernimento e o conhecimento. ${ }^{10} \mathrm{Com}$ tal abrangência, é possível vislumbrar os danos que qualquer alteração corpórea poderá acarretar. Além disso, considerando o mecanismo das sensações, percebe-se que todas as faculdades acima enumeradas estão vinculadas ao movimento dos espíritos animais e, portanto, atreladas a um mecanismo. Mas não só a faculdade sensitiva é considerada por La Mettrie; as faculdades intelectuais (ou alma racional) são enfocadas sob o mesmo prisma da sujeição. Percepções intelectuais, liberdade, atenção, reflexão, ordem ou organização das ideias, exame e julgamento (cf. La Mettrie, 1987b, p. 209) são apontados como faculdades da alma racional. Todas elas se referem às sensações que afetam a alma, dependem da faculdade de sentir e servem como reforço para a defesa da posição lamettriana segundo a qual a alma é substância física, conforme ele inicia sua argumentação no Tratado da alma, defendendo as propriedades acima referidas. Assim, todas as operações da alma devem se referir, em última instância, à organização do corpo. ${ }^{\mathbf{1 1}}$ Mesmo as faculdades intelectuais, que para La Mettrie vão além do campo das sensações e voltam-se para a consideração da liberdade, da reflexão e da ordenação das ideias, dependem das faculdades orgânicas: quanto melhores forem elas, melhor será o espírito. Para amparar essa afirmação, o autor recorre a exemplo pautado na patologia. Uma doença cerebral impede as operações da

10 Abrangência que remete, mais uma vez, à obra de Lamy, Explicação mecânica e física das funções da alma sensitiva, ou dos sentidos, das paixões e do movimento voluntário.

11 Nesse ponto, La Mettrie afirma sua concordância com os antigos (cf. 1987b, p. 22, 220). Os antigos aos quais La Mettrie se refere em suas obras e em questões diversas, para além da dependência da mente ao corpo, são Epicuro e Lucrécio, no que diz respeito à rejeição ao finalismo e à crítica à imortalidade da alma; Aristóteles, quanto à noção de forma; a filosofia escolástica, na defesa das formas substanciais, enquanto constituem a força motriz da matéria, e na consideração da existência da alma unida à matéria. De forma geral, os antigos são invocados sob a autoridade de Aristóteles, como crítica à desertificação do mundo operada pela visão geométrica do universo que desconsidera a natureza orgânica do mundo. O Breviário dos sistemas para tornar fácil a compreensão do tratado da alma, de 1751, oferece um panorama sobre as referências aos antigos no que diz respeito à mortalidade da alma (cf. La Mettrie, $19^{8} 7$ c, p. $\left.269^{-} 7^{6}\right)$ 
alma ao prejudicar a comunicação das ideias entre o cérebro e os órgãos dos sentidos. Essas faculdades estão, assim, atreladas à faculdade de sentir; elas dependem desta de forma essencial: "sem ela, a alma jamais executaria qualquer uma de suas funções" (La Mettrie, 1987b, p. 221). Para fortalecer essa afirmação, La Mettrie encerra a obra com um capítulo voltado exclusivamente para casos que confirmem as ideias aí defendidas. O Tratado da alma contém, no final das contas, uma teoria das sensações, como o próprio autor afirma ao final de sua exposição (cf. La Mettrie, 1987̧b, p. 243).

A descrição das ações da mente sob o ponto de vista físico encontrada nessa obra constitui-se como base para a abordagem moral que se inicia em Ohomem-máquina e ganha corpo nas obras posteriores. No Tratado da alma encontra-se a afirmação da dependência das inclinações em relação "à estrutura particular dos sentidos, da solidez, da moleza dos nervos que se encontram nesses órgãos, ou antes, que os constituem" (La Mettrie, 1987b, p. 184). Tal consideração estará presente no desenvolvimento do enfoque moral que consta em suas obras posteriores. Nela, também encontramos a vinculação entre felicidade e causas corporais, a combinação entre conformação dos órgãos e forma de encarar a vida (p. 192), tão cara ao desenvolvimento do ponto de vista moral que ganhará destaque a partir de O homem-máquina, com a ênfase na dependência de nossas inclinações em relação à constituição do corpo.

Apesar do esforço em defender a existência de movimento na matéria, La Mettrie não parece levar a bom termo sua defesa, uma vez que, ao se valer de termos caros à escolástica, sua exposição deixa aberta a possibilidade de uma intervenção externa à matéria, ao modo de uma potência motriz situada fora dela. Essa "falha" em sua exposição se dá no momento em que recorre ao que foi denominado "forma substancial", especificamente à "forma substancial ativa". La Mettrie, no Tratado da alma, afirma que a matéria, para atualizar suas propriedades, deve ser revestida de "algumas formas que lhe dêem a faculdade de se mover e de sentir" (La Mettrie, 1987b, p. 14,3). Formas essas que aperfeiçoam a matéria e fazem parte dela, de alguma maneira. Nesse ponto de sua exposição, o autor, ao promover uma classificação das formas substanciais (cf. La Mettrie, 1987b, cap. ₹), destaca as que são tidas como princípio de vida nos corpos vivos, reunidas sob a denominação "alma" que se divide em três tipos: vegetativa, sensitiva e racional. Ora, é justamente no reconhecimento dessas formas substanciais que se localiza uma contradição reconhecida, pois dois anos depois da publicação em 1745 da História da alma, La Mettrie publica sua obra mais conhecida, O homem-máquina. Afinal, aceitar tais formas implica afirmar que a força motriz está situada fora da matéria, uma vez que seria preciso conhecer de onde vem tal forma substancial que lhe dá movimento, que atualiza essa potência de se mover. Mas se tal forma faz parte da matéria, como ele mesmo afirma, então seria preciso recorrer a outra matéria igualmente revestida dessa forma substancial para lhe comunicar o movimento e, assim, sucessi- 
vamente até chegar a um princípio ativo externo a ela. La Mettrie critica a "ressurreição" desses termos que não só estão carregados de imprecisão, uma vez que geram uma explicação insuficiente por remeter ao movimento para explicar o movimento, como também recorrem a seres de razão. ${ }^{12}$ Essa autocrítica estabelece um marco na obra lamettriana, pois a partir de então a estrutura de seus textos filosóficos, dos quais são banidas as formas substanciais emprestadas à tradição escolástica, não mais se apresentará nos moldes de um tratado metafísico, ou pelo menos com pretensão a tal.

\section{De $O$ homem-máquina ao Discurso preliminar:}

\section{A DEPENDÊNGIA DO MORAL EM RELAÇÃO AO FÍSIGO}

Vejamos como se dá a abordagem em sua obra mais referida, $O$ homem-máquina, na qual o entrelaçamento entre os pontos de vista médico, filosófico e moral se mostra de forma inequívoca. Se, como foi afirmado acima, no Tratado da alma há uma ênfase do autor na prevalência da faculdade sensitiva em relação à intelectiva, no texto de 1747 a explicitação da dependência das atividades mentais em relação ao corpóreo e a importância que ganha a organização da matéria são pontos fundamentais para o fortalecimento da interpretação materialista do homem em La Mettrie.

O título da obra cria a ilusão no leitor de que se trata de uma interpretação do homem sob o ponto de vista mecânico, de forma tal que ele poderá ser comparado a um relógio, só para aludirmos ao mecanismo mais referido na época. No entanto, nada está mais distante dessa imagem do que o conteúdo dessa obra, uma vez que a interpretação materialista aí desenvolvida envolve aspectos que vão além dessa simplificação. $\mathrm{O}$ mesmo ocorre com a obra 0 homem de Descartes. Texto inacabado que, mesmo incompleto, não reduz o homem a uma máquina. Em La Mettrie, a referência à máquina diz respeito não a uma descrição do funcionamento do organismo a ser apresentada com base no mecanismo, mas visa proporcionar, a partir da aceitação de um dinamismo existente na matéria, uma compreensão do homem unicamente por meio da física, de forma que fique claro que apenas as leis físicas exercem domínio sobre todas as suas funções corpóreas, que incluem as sensoriais e as mentais. Dessa maneira, os sentidos, os sentimentos e a intelecção ficam submetidos às mesmas leis sobre as quais o homem não tem controle algum. Em outras palavras, um fatalismo se instala nessa concepção lamettriana, que trará consequências morais, como veremos mais adiante.

12 Sobre essa autocrítica, o estudo de Aram Vartanian, que antecede sua edição do Homem-máquina, é bastante elucidativo. A referência a uma carta de La Mettrie a Mme. du Châtelet publicada em 1747, junto com uma edição da História da alma (cf. La Mettrie, 1999), mostra a preparação dessa crítica que estará presente n’O homem-máquina (cf. Vartanian, 1960, p. 40-56; La Mettrie, 1987d, p. 109). 
O método a ser adotado pelo autor, sempre se pautando na observação e na experiência, será emprestado da medicina, a saber, da anatomia comparada. Por meio desse método, são traçados, ao longo do texto, paralelos entre o homem e o animal não só no que diz respeito à organização física, mas também quanto ao comportamento. ${ }^{\mathbf{1 3}}$ O homem-máquina, ao defender a interpretação segundo a qual só há uma matéria em todo o universo do qual o homem participa, matéria essa que é dotada de um dinamismo tal que produz todas as faculdades atribuídas ao homem e aos animais, ${ }^{\mathbf{1 4}}$ procura reforçar a tese da imanência, esboçada com dificuldade no Tratado da alma, quando defende a eliminação do recurso a uma causa imaterial.

A contradição engendrada pela adoção das formas substanciais indica a dificuldade em melhor defender a tese do dinamismo da matéria. Airritabilidade é apresentada como a base para a constituição do princípio explicativo do movimento da matéria, uma vez que a doutrina das formas substanciais foi criticada por ser ininteligível (cf. La Mettrie, 1987b, p. 109). La Mettrie, ao adotar e adaptar a noção de irritabilidade fibrilar, ${ }^{\mathbf{5}}$ a transforma em princípio motor que se aplica a corpos inteiros e a partes destacadas do conjunto, em todos os animais, independentemente de sua temperatura e de sua compleição física. A irritabilidade apresenta-se como a propriedade que pode dar conta do movimento da matéria sem qualquer recurso externo a ela. As experiências mostram como se manifesta tal propriedade nos músculos destacados do corpo, no coração de uma rã, nas vísceras abdominais que conservam seu movimento peristáltico, nos pólipos que, ao serem seccionados, reproduzem-se. A matéria movese por si mesma e a experiência é suficiente para demonstrar essa força da matéria, não sendo necessário conhecer como se inicia essa atividade, uma vez que isso ultrapassa os limites impostos pelo método adotado. A partir de então, está formada a base que possibilitará a La Mettrie passar para a explicação da atividade mental, como extensão de sua interpretação materialista.

Primeiramente, é importante considerar o que o autor entende por alma, ela é "parte material sensível do cérebro que pode ser considerada, sem receio algum, como a principal engrenagem de toda a máquina e que tem visível influência sobre todas as

13 Esse paralelo remete a Descartes e sua discussão em torno da existência ou não da alma nos animais. Esse assunto, por sua abrangência e complexidade, uma vez que Descartes não apresenta uma posição tão clara a seu respeito, como indica a sua correspondência, comportaria um estudo específico que ultrapassa a proposta deste trabalho (cf., por exemplo, AT, 7, p. 426; AT, 9, p. 228; AT, 4, p. 73-5; AT, 5, p. 275-7; Guichet, 2010).

14 Mais uma vez, a importância de Willis se apresenta. Nessa obra, La Mettrie refere-se várias vezes ao médico inglês cujas obras Cerebri anatome e De anima brutorum são mencionadas por darem apoio à sua posição referente à sensibilidade existente nos homens e nos animais com base no exame da estrutura cerebral.

15 Não pode deixar de ser considerada a descoberta de Albrecht Haller - irritabilidade - que serviu de base para La Mettrie sustentar a existência de uma atividade autônoma da matéria, como pode ser verificado em várias passagens de sua obra O homem-máquina. 
outras" (La Mettrie, 1987b, p. 105). Temos aí a consideração de um mecanismo responsável pelo movimento dos demais, além do reforço da superfluidade em se recorrer a uma substância espiritual, pois a matéria é suficiente para dar conta de todas as operações que um organismo é capaz de desempenhar. Em seu apoio, são mencionados exemplos pautados na prática médica, como "quando o sentimento se extingue, o pensamento também se ausenta como na apoplexia, na letargia, na catalepsia etc." (1987b, p. 109). Nessa mesma linha de raciocínio, é observado que as doenças podem transformar o mais sagaz dos homens em um verdadeiro idiota, de forma tal que toda a grandiosidade do conhecimento adquirido se esvai. Nesse contexto, a imaginação desempenha importante papel, uma vez que ela está relacionada às vísceras, nas quais basta uma obstrução para que a imaginação fique alterada, engendrando mudanças que estão na base da hipocondria e da histeria. ${ }^{16}$ É importante ressaltar que a imaginação, para La Mettrie, constitui-se como a principal faculdade pelo fato de estabelecer a ligação entre a intelecção e a sensação. As ideias, a exemplo do que defende Locke, originam-se a partir do momento em que os objetos afetam os sentidos que levam a informação ao cérebro, mas a qualidade dessa informação sofre variações conforme o estado em que se encontra o corpo. Assim, a matéria prima do conhecimento são as ideias sensíveis. A função da memória é importante por possibilitar que a mente não fique limitada ao momento em que se dá a assimilação de uma ideia, o que reduziria a apreensão das ideias ao momento em que ocorre uma sensação, ou seja, a mente poderia contemplar uma só ideia. Com a memória, o movimento da mente consegue ultrapassar o momento presente e isso se dá por meio dos vestígios que os espíritos animais deixam na superfície do cérebro, no movimento de refluxo. Tem-se, dessa maneira, a passagem de uma ideia a outra, a consequente relação que se estabelece entre elas e, a partir daí, são forjadas operações tais como o julgamento. A imaginação vai se servir das ideias recuperadas pela memória, de modo a produzir novas ideias a partir de uma combinação, fusão ou alteração entre elas. Mas não se trata, aqui, de lidar com ideias causadas por objetos externos, mas sim de considerar causas internas que as produzem. No que diz respeito à imaginação, devem ser consideradas causas materiais ocultas (causes cachées) que afetam uma parte do corpo. O processo de produção da ideia é o mesmo das ideias sensíveis, mas sem a presença de um objeto externo. Tratase de considerar os sentidos internos na base das mudanças dos pensamentos na formação dos objetos da imaginação. Por se tratar de um processo que envolve causas internas, os sentidos internos, o papel do corpo na imaginação é muito mais acentuado do que no caso da produção das ideias sensíveis. E sua importância se faz sentir na abordagem

16 A defesa da base orgânica de distúrbios mentais é encontrada em médicos que adotaram os princípios do iatromecanicismo de Boerhaave, como por exemplo o escocês Robert Whytt (1714-1766), autor do Traité des maladies nerveuses, hypocondriaques et hystériques. 
de La Mettrie por indicar, a partir dos estados corpóreos, os estados da mente; os delírios e as vertigens, que podem ser favoráveis aos artistas ou desfavoráveis aos melancólicos, ainda podem, em outros casos, provocar o furor, e estão presentes também nos maníacos, quando se fixam em uma determinada ideia. A importância que La Mettrie dá à organização do cérebro, principalmente em 0 homem-máquina, situa-se no papel que os sentidos internos desempenham na criação das ideias no âmbito da imaginação. Conforme a organização do cérebro, que é diferente entre os indivíduos, tem-se a determinação do caráter de cada um, sem desconsiderar os fatores externos que interferem, como é o caso da educação. Por isso, a imaginação é tida como o foco central da inteligência, quando as informações provenientes da percepção são recuperadas pela memória e trabalhadas pelos sentidos internos de forma a transformálas em novas ideias.

A influência sobre a alma de substâncias tais como o ópio, o vinho, o café e alguns alimentos também é útil para provar a dependência da alma em relação aos estados do corpo (cf. La Mettrie, 1987d, p. 7o). Em todos esses exemplos, La Mettrie valese da fisiognomonia e da anatomia comparada. Pela fisiognomonia, ao mencionar o texto de Jacques Pernetti, Cartas sobre as fisionomias, La Mettrie vincula as qualidades do espírito com aspectos do rosto e a constituição física. Pela anatomia comparada, ele pretende demonstrar aquela dependência por meio do paralelismo entre as estruturas do homem e do animal. A estrutura do homem deve ser considerada em comparação com a dos animais, estando todos submetidos às mesmas leis e sujeitos à destruição. $\mathrm{Na}$ adoção desse continuísmo material, que mostra a existência de uma unidade na natureza, na qual é observada uma escala que apresenta gradações de forma a não há saltos em suas produções (cf. La Mettrie, 2003), encontramos o ponto que possibilita a vinculação entre filosofia e medicina, bem como a inserção da questão moral.

Ao adotar a anatomia comparada como componente de seu método, La Mettrie defende o continuísmo que é observado na natureza. Nesse continuísmo, o homem integra-se com os outros animais, uma vez que todos pertencem à mesma natureza $\mathrm{e}$ possuem inteligências adequadas às suas necessidades. Os seres vivos apresentam diferenças nas faculdades de se mover e de sentir que se conformam às suas necessidades, e tais diferenças não devem justificar a construção de uma hierarquia de forma a colocar o homem em seu grau mais elevado. Todos são portadores de uma inteligência voltada para as suas necessidades. As variações constatadas na natureza servem para provar, segundo La Mettrie, "ao menos a necessidade de uma boa e abundante organização, pois em todo o reino animal a alma, ao se fortalecer com o corpo, adquire sagacidade à medida que este ganha força" (La Mettrie, 1987d, p. 75). As diferenças qualitativas entre homem e animal desaparecem e ganha destaque a relação de dependência das faculdades da alma para com a organização do cérebro e de todo o corpo. A organi- 
zação, aliás, passa a ocupar o centro não só das explicações da máquina corpórea, mas também do corpo sensível. As variações de estrutura compõem a base explicativa dos processos orgânicos que envolvem igualmente a capacidade de pensamento, sempre permeados pelo movimento. Com isso, o autor desqualifica o termo "alma”.

A alma é apenas um termo vão de que não se tem nenhuma ideia e do qual um espírito esclarecido só se deve servir para denominar a parte que em nós pensa. Admitido o menor princípio de movimento, os corpos animados terão tudo o que lhes é necessário para se mover, sentir, pensar, arrepender-se e, em uma palavra, se conduzir na física e na moral que dele depende (La Mettrie, 1987d, p. 98).

Nessa concepção imanentista, surgem questões de caráter metafísico e religioso referentes à exclusão das diferenças entre o homem e o animal. Se ambos são dotados de sensibilidade e se os seres sensíveis se originam a partir das combinações da matéria com ela mesma, não há mais sentido em se postular um princípio externo à matéria como causa primeira e em defender uma alma que seja imaterial e imortal.

A questão referente à busca de uma causa primeira, de um primeiro motor, apresenta-se desprovida de sentido, trata-se de uma quimera, pois ultrapassa os limites de nossa capacidade de conhecimento, que está pautada na sensibilidade. Essa limitação não oferece condições para que possamos fazer qualquer afirmação sobre a eternidade ou sobre a criação do mundo. A discussão ontológica sobre origem não tem lugar no universo lamettriano, o que pode ser constatado em sua recusa em acatar seja a posição deísta, seja a anticriacionista (La Mettrie, 1987d, p. 93- $)$.

A defesa da diferença entre a inteligência humana e a animal como sendo uma diferença de grau, posto que ambos sejam dotados de alma, apresenta-se como uma afronta perante os teólogos. Pelo exame da estrutura cerebral não se encontram diferenças que justifiquem a primazia do homem em relação aos animais e o lugar privilegiado junto a um criador. Não havendo diferenças e a alma podendo ser explicada materialmente, a questão referente ao pecado também perde sentido, pois não há transcendência que ofereça sustentação para colocar um freio nas disposições humanas que levam a atos passíveis de condenação, com a promessa de um mundo melhor situado para além deste.

O que filósofos como Descartes e Malebranche, entre outros, chamam de alma imortal e racional apresenta funções que podem ser explicadas a partir da organização da matéria. Com a adoção da anatomia comparada, as funções da alma são compreendidas como funções fisiológicas que requerem uma estrutura determinada para terem bom desempenho. Estrutura esta que, não custa repetir, está presente nos animais com algumas variações. 
Em geral, a forma e a composição do cérebro dos quadrúpedes é mais ou menos a mesma que no homem. Mesma configuração, mesma disposição por toda parte, com esta diferença essencial: o homem, de todos os animais, é aquele que tem mais cérebro e o cérebro mais tortuoso em razão da massa de seu corpo; em seguida o macaco, o castor, o elefante, o cachorro, a raposa, o gato etc. Eis os animais que mais se assemelham ao homem (La Mettrie, $1987 \mathrm{~d}, \mathrm{p} .7^{3}$ ).

Assim, o foco central localiza-se na estrutura dos corpos organizados que só pode ser conhecida por meio da observação e da experiência. Apenas dessa maneira teremos condição de conhecer a natureza do homem. É nessa ênfase que encontramos a consideração de aspectos morais, uma vez que, para La Mettrie, a base moral encontra-se na organização e na instrução. O papel da organização está constantemente acentuado em O homem-máquina, uma vez que aí se encontra, reiteradas vezes, a afirmação segundo a qual as faculdades sensíveis e intelectuais dependem da organização de cada indivíduo, que se mostra única. A base de tal afirmação já se encontra no Tratado da alma (ver seção 1 acima).

Tantos temperamentos, tantos espíritos de caracteres e costumes diferentes. O próprio Galeno conheceu esta verdade que Descartes levou mais adiante, a ponto de afirmar que apenas a medicina poderia mudar, por meio do corpo, os espíritos e os costumes. É verdade que a melancolia, a bile, a fleuma, o sangue etc., conforme a natureza, a abundância e a diversa combinação desses humores, fazem de cada homem um homem diferente (La Mettrie, 1987d, p. 67).

A teoria dos humores, colocada na base da singularidade do sujeito, acentua o caráter materialista dessa interpretação. Anatureza humana, na concepção lamettriana, limita-se a esse universo material que está na base de todas as explicações, aí incluindo a moralidade. A afirmação segundo a qual "a alma segue os progressos do corpo" é pautada em exemplos tirados da patologia, tais como as alterações comportamentais que uma lauta refeição pode provocar; doenças que provocam mudanças tais a ponto de transformar um tolo em um homem atilado e vice-versa; as ilusões dos amputados; a loucura como efeito de obstruções das vísceras abdominais; a influência dos desregramentos das paixões sobre o funcionamento do organismo e outros tantos exemplos tirados do exercício de sua profissão. Se a alma segue as modificações do corpo, o mesmo acontece em relação às que ocorrem com a educação. Neste ponto, a crítica de La Mettrie volta-se para os autores que tratam da moral sem levar em consideração a organização do corpo, privilegiando a educação. Afinal, toda a indústria do homem está pautada nessa organização, na disposição que possibilita que nos tornemos "hábeis, sábios e 
virtuosos" (La Mettrie, 1987 d, p. 83). É assim que a educação se torna o segundo mérito do homem, depois da organização, que é a fonte de todos os outros que podem ser atribuídos ao homem. Organização do corpo e instrução encontram-se entrelaçados, pois uma boa constituição corpórea sem qualquer instrução constitui um desperdício, da mesma maneira que uma boa assimilação das ideias requer uma base corpórea bem organizada. A educação apresenta-se com poderes limitados pela organização do corpo, uma vez que esta define cada um de nós, fazendo que a instrução seja dependente de nossa constituição orgânica. A função da instrução aparece claramente como sendo a de formar o que La Mettrie chama de "espírito", ou seja, desenvolver a inteligência. Para isso, ela requer um cérebro bem constituído, bem como órgãos dos sentidos saudáveis, pois, sem essa "matriz perfeitamente permeável à entrada ou à concepção de ideias", a educação não tem como apresentar os seus frutos (cf. La Mettrie, 1987 d, p. 83). Assim, a base orgânica é fundamental nesse processo de educação. É essa base orgânica que coloca o homem próximo do animal e constitui o continuísmo defendido por La Mettrie, e isto de tal modo que o que vale para um vale para o outro. Em outras palavras, sai o recurso à alma imortal, da qual apenas o homem seria portador e o colocaria em um nível diferente e distante em relação aos animais, e entra a matéria organizada com a capacidade de produzir sentimentos que se apresentam igualmente em homens e animais. A diferença entre eles consiste no menor número de ideias e de suas expressões presentes nesses últimos, e no verniz da educação nos primeiros (cf. La Mettrie, 1987 b, p. 243). Importante ressaltar que a similaridade observada na organização física e no comportamento dos homens e dos animais não exclui, para La Mettrie, a consideração da possibilidade de, por exemplo, ensinar um macaco a falar, sempre considerando as condições orgânicas do animal que tornem possível chegar a tal fim (cf. La Mettrie, 1987 d, p. $75^{-8}$ ).

A instrução coloca o homem em um nível diferenciado em relação aos animais, mas não o exclui dessa classe. Ainda que em alguns pontos o homem esteja abaixo do nível das habilidades observadas nos animais (cf. La Mettrie, 1987d, p. 86-7), eles estão próximos em um ponto, pois ambos apresentam o sentimento de arrependimento. Podemos constatar em nós, por meio do pensamento, o sentimento de remorso que se segue a um determinado ato; quanto à existência de tal sentimento nos outros, a linguagem, os sinais externos e sensíveis apresentam-se como meios de constatação, tomando como referência nossa própria experiência. Quanto aos animais, para que possamos julgar a existência neles de tal sentimento, na ausência do discurso, devemos recorrer aos sinais externos. Com esse recurso é possível detectar o mesmo sentimento que se costuma imputar apenas aos homens. No âmbito moral, a reafirmação da igualdade entre homem e animal, já estabelecida com base nas estruturas físicas similares, 
volta-se para a existência de um sentimento comum que se inscreve como uma lei natural à qual nenhum organismo se furta. Sempre tomando por base a observação, é possível constatar nos animais a percepção de ter cometido uma falta, "o cachorro que mordeu seu dono, porque este o irritava, pareceu se arrepender disso no momento seguinte; viram-no triste, abatido, não ousando se mostrar, declarando-se culpado através de seu ar servil e humilde" (La Mettrie, 1987d, p. 88).

La Mettrie vale-se da denominação "lei natural" para esse conhecimento do bem e do mal, estendendo a sua presença para todos os seres vivos. Tal ampliação serve para reforçar sua posição contra a diferença entre o homem e o animal defendida com base na existência da alma imaterial e imortal que só o homem possuiria. Ao ser suprimida a hierarquia, uma espécie de intercâmbio se instaura; o que vale para o homem passa a valer para o animal, de forma que a moral deverá se pautar por critérios sensoriais. Nesse ambiente, a base dos "desvios de conduta" também está localizada em desarranjos orgânicos, físicos. Se for concedido que os animais não sejam portadores dessa lei natural, o mesmo deve ser considerado em relação ao homem, uma vez que ambos são formados pela mesma matéria e apresentam estruturas físicas muito próximas. E com isso, "adeus a todos esses belos tratados que foram publicados sobre ela! Todo o reino animal ficaria inteiramente desprovido dela!" (La Mettrie, 1987d, p. 90). Havendo apenas uma diferença de grau entre homem e animal, ambos participam "das mesmas prerrogativas da animalidade"; não pode haver alma sem o sentimento de remorso.

Essa lei natural, não podendo ser destruída, deve ser considerada a possibilidade de crimes serem interpretados como resultados da influência de algum desarranjo físico, do temperamento, e não como atos voluntários. Em outras palavras, trata-se de considerar o determinismo físico e a ausência de controle sobre atos que o têm por base. Determinismo este que se volta para a valorização da determinação biológica, dos instintos, e compõe a base da afirmação do homem como máquina. Na análise dos atos humanos, a hereditariedade é levada em consideração e constitui-se como um reforço do determinismo defendido. Segundo La Mettrie, os vícios assim como as virtudes são passíveis de transmissão de pais para filhos, "da mesma forma como os da ama passam para aqueles que ela amamenta" (La Mettrie, 1987d, p. 91).

Penso o mesmo de todos os que cometeram crimes, ainda que involuntariamente ou por temperamento: de Gaston d'Orléans que não podia se impedir de roubar; de certa mulher que estava, durante a gravidez, sujeita ao mesmo vício que foi herdado por seus filhos; (...) da filha de um ladrão antropófago que se tornou igual a ele aos 12 anos, ainda que tenha perdido o pai e a mãe quando tinha um ano e tenha sido criada por pessoas honestas (La Mettrie, 1987d, p. 90-1). 
Tudo se resolve no organismo, sem que haja qualquer deliberação, de modo que aqueles que cometem atos monstruosos e apresentam remorsos logo em seguida, quando recobram a consciência, indicam que os cometeram por não terem como fugir dessa imposição, dessa necessidade orgânica, a exemplo do que ocorre com a bulimia que "é uma doença do estômago que somos forçados a satisfazer" (p. 91).

Nessa concepção determinista, o crime já traz em si a própria punição, que é o arrependimento, o sentimento de culpa que passa a corroer aquele que agiu erroneamente, enfim, a própria consciência do ato torna-se o algoz mais eficaz.

Eu não quero dizer que todos os criminosos sejam injustamente punidos, afirmo apenas que aqueles cuja vontade está depravada e a consciência extinta são suficientemente punidos por seus remorsos, quando voltam a si; remorsos, ouso dizer, de que a natureza deveria, nesse caso, ter privado os infelizes que são arrastados por uma fatal necessidade (La Mettrie, 1987 d, p. 92).

Dessa maneira, tanto o crime como a virtude devem ser relacionados com a organização, com a máquina, em outras palavras, devem ser consideradas as leis que regem o funcionamento do organismo. Por entender que essas leis devem sobrepujar as leis humanas, La Mettrie defende que os juízes sejam médicos. Afinal, os crimes, os atos violentos e quaisquer destemperos podem ser consequência de um desarranjo orgânico que só os médicos têm condições de avaliar. Com isso, seria evitada a desproporção entre as penas e os atos cometidos involuntariamente, "somente eles [os médicos] poderiam distinguir o criminoso inocente do culpável" (La Mettrie, 1987d, p. 91). Mas os médicos aqui considerados são os que adotam a experiência, a observação, a física na composição da análise semiológica, ou seja, os que consideram o sangue, a tendência, como será afirmado posteriormente no Anti-Sêneca ou discurso sobre a felicidade (cf.

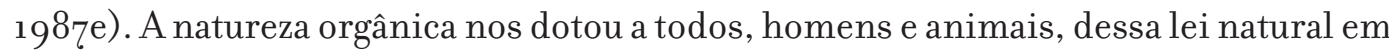
proporção adequada ao comportamento de nossos órgãos. Entendida como um sentimento que indica que não devemos fazer aos outros aquilo que não desejamos que nos façam, trata-se da regra de conveniência já tão bem explorada por Locke no Ensaio sobre o entendimento humano: respeitamos os bens e a vida dos outros para preservar nossos bens e nossas vidas. Essa lei natural, anterior às leis civis, é permeada pela consciência, reúne o instinto, inscrito na própria natureza orgânica, e o interesse de preservação.

Na concepção continuísta, que permeia toda a obra de La Mettrie, fica compreensível a afirmação segundo a qual o plano moral depende do físico (cf. La Mettrie, 1987 d, p. 98). A diferença entre homem e animal reduzindo-se à quantidade e à disposição de peças componentes da máquina corpórea, e a organização do corpo do ser vivo produzindo a consciência e o sentimento de remorso, percebe-se uma continuidade 
entre o plano físico e o plano moral, de tal forma que o primeiro estabelece as condições de desenvolvimento do segundo. Mas, ao voltarmo-nos para as obras posteriores a Ohomem-máquina, notamos que a dependência da moral em relação à física torna-se mais acentuada; essa noção de lei natural, vinculada ao remorso, é banida, e a razão desse desaparecimento não se mostra claramente. Talvez isso se deva ao fato de essa noção remeter a pontos rejeitados por La Mettrie, ${ }^{\mathbf{1} 7}$ ao indicar que somos dotados de uma faculdade que nos leva a seguir essa lei e a fazer o bem, já que é afirmado que não há prazer maior do que fazer o bem, e nem tanto contentamento quanto seguir a virtude. Além disso, ao voltarmo-nos para o conceito de felicidade nesse autor, que está atrelado à máquina orgânica como qualquer outro sentimento, notamos um descompasso entre essa lei natural, ou esse sentimento de remorso, e a felicidade que todos buscamos. Ou ainda, como o próprio autor afirma em seu constante exercício de autocrítica, talvez isso se deva a uma incompreensão do texto Exame da religião, atribuído a Charles de Saint Evremond (cf. La Mettrie, 1987e, p. 261). ${ }^{\mathbf{1}}$ Se em Ohomem-máquina é afirmado que estamos destinados, por natureza, a sermos felizes, ${ }^{19}$ no Anti-Sêneca ou Discurso sobre a felicidade, ${ }^{20}$ texto de $175^{\circ}$, a felicidade mais constante é caracterizada como aquela que depende da organização do corpo (cf. La Mettrie, 1987e, p. 24, o) e que não pode ser abalada pelo remorso, que se mostra como uma ameaça a ela. Nessa obra, fica bem marcada a influência da formação médica do autor sobre suas considerações morais, pois o homem deve ser compreendido com base na matéria, ou seja, sob o ponto de vista físico. A felicidade aparece como consequência da constituição física de cada indivíduo e vincula-se ao bem-estar. Nota-se que, nessa caracterização de felicidade, o tratamento dispensado por La Mettrie está voltado para a felicidade individual que leva em consideração não só a disposição do corpo, a partir da qual cada um de nós é levado a ela, mas também a interferência da educação, principalmente a educação religiosa. E é nesse fator externo, a educação, que reaparece o problema referente ao remorso. O organismo nos leva, poderíamos mesmo afirmar que ele nos força, a procurar a felicidade, de forma que essa busca é dirigida por um impulso que não elimina o estímulo sensorial. A felicidade, assim gerada, é orgânica, como podemos depreender do texto.

17. Como, por exemplo, o caráter inato de que se reveste a lei natural que, por sua vez, remete à aceitação de um criador que estaria por trás dessa ordenação voltada para um fim (cf. Thomson, 1981, p. 47).

18 Examen de la religion dont on cherche l'éclaircissement de bonne foi, primeira edição de 1705 , obra deísta que contém críticas aos dogmas cristãos e defende a existência do bem e do mal apenas no âmbito da sociedade, onde o remorso fica justificado como proveniente do preconceito, da educação.

19 "A natureza nos criou a todos unicamente para sermos felizes. Sim, todos: desde o verme que se arrasta até a águia que se perde na nuvem" (La Mettrie, 1987e, p. 92).

20 Texto elaborado como apresentação à tradução do Tratado sobre a vida feliz, de Sêneca, publicada por La Mettrie e que já indica a sua oposição à felicidade defendida por Sêneca. 
Nada prova melhor que é uma felicidade de temperamento, do que todos esses imbecis felizes que cada um de nós conhece, enquanto tantas pessoas de espírito são infelizes. Parece que o espírito tortura o sentimento. Ademais, os animais vêm ao apoio desse sistema. Quando eles estão saudáveis e seus apetites estão satisfeitos, eles gozam o sentimento agradável ligado a essa satisfação e consequentemente essa espécie é feliz a sua maneira (La Mettrie, 1987e, p. 243).

Se estamos destinados à felicidade, devemos evitar tudo o que possa atrapalhar esse fado. No Anti-Sêneca, o remorso é afirmado como engendrado pela educação que inculca preconceitos desde a infância, eclipsando os instintos naturais e menosprezando os prazeres físicos, por isso ele deve ser evitado. Assim, a sociedade, com o auxílio da religião, torna-se responsável por esse dano causado ao homem ao condicionálo a certo comportamento, de tal forma que o hábito faz que lhe pareça natural. Temos aí algo como a constituição de uma segunda natureza, que entra em conflito com a natureza original e que mostra toda a sua força ao preponderar sobre o artifício. No entanto, essa segunda natureza também detém alguma força a ponto de provocar o remorso, o sofrimento, o mal-estar conforme a constituição de cada um. A exemplo da autocrítica encontrada em $O$ homem-máquina, no que diz respeito ao banimento das formas substanciais, no Anti-Sêneca é encontrada uma referência ao erro, como ele próprio denomina, no texto anterior, ao considerar o remorso como existente em todos os seres vivos, além de reafirmar o erro no recurso às formas substanciais tal como aparece no Tratado da alma (cf. La Mettrie, 1987e, p. 260-1). Tal "erro" pode ser atribuído a uma falta de conhecimento da natureza do remorso, tal qual exposta no texto Exame da religião, ${ }^{\mathbf{2 1}}$ ou hesitação em enfrentar os preconceitos mais arraigados. Sua origem permanece indeterminada, mas o fato é que, a partir dessa obra, La Mettrie desloca o remorso para o campo do artifício, colocando-o como fator externo que se constitui como obstáculo à felicidade e gera o sofrimento com repercussão orgânica, ou seja, o sofrimento psicológico.

Ao dar vazão aos nossos instintos, às nossas tendências, nada mais fazemos do que seguir a ordem da natureza. Isso significa que "somos levados em direção ao nosso bem próprio de forma maquinal e nascemos com essa propensão e essa disposição invencível" (La Mettrie, 1987e, p. 263) e é dessa maneira que nos sentimos felizes. Para La Mettrie, é indiferente a propensão ao bem ou ao mal, o que importa é o prazer

21 A incompreensão da obra atribuída a Saint Evremond, mencionada na nota 18. Ann Thomson cita um trecho da edição de 1761do Exame da religião que indica ser a causa mais provável dessa alteração, em La Mettrie, a falta de uma leitura mais atenta, "os remorsos são provenientes apenas do preconceito (...) quando nossa máquina está esgotada pelos espíritos agitados na paixão, então as antigas ideias são despertadas e causam o remorso (fim do cap. 9)” (Thomson, 1981, p. 24,0). 
resultante dessa felicidade. Essa indiferença pode dar a impressão de que o autor procura legitimar o crime, uma vez que ele defende a felicidade individual, sem virtude, e que até está presente nos crimes. Mas não se trata disso, como veremos mais adiante.

Por natureza, somos levados, o que significa dizer que somos determinados, tanto a cometer delitos como ações virtuosas que nos proporcionam bem-estar. A sociedade, como forma de preservação da convivência entre os homens, intervém com mecanismos de repressão a esses impulsos, dentre os quais se destaca a educação que procura alterar os sentimentos de forma a afastar o homem de sua natureza original, em uma espécie de domesticação, mas a natureza sempre terá mais força e não pode ser apagada. Daí a necessidade de construção de regras e de conceitos tais como de justiça e injustiça, bem e mal para a preservação do interesse geral. Mas se o homem é levado a cometer crimes, uma vez que não tem qualquer repressão interna e tudo o que faz está embasado na determinação dos estados corporais, como lidar com o conflito entre o natural e o artifício que pune? No contexto do Anti-Sêneca, o remorso aparece como antinatural, torna-se fonte de infelicidade e gera o temor da punição eterna que leva ao sofrimento psicológico. Além de ser contranatural, o remorso de nada serve, pois ao surgir depois de consumado o ato, não o previne e tampouco o altera. Em outras palavras, ele apenas gera um sofrimento absolutamente desnecessário. A inutilidade do remorso é afirmada considerando que ele acaba por afetar em maior grau aqueles que, eventualmente, entregam-se a sentimentos que não conseguem controlar, enquanto os piores criminosos quase não são fustigados por tal sentimento.

A interpretação materialista lamettriana, ao focar o homem como determinado fisicamente, procura tirar o peso que o arbítrio das leis lhe impinge com a consequência nefasta provocada pelo sofrimento que advém do remorso. Não se trata de defender ou de tolerar a entrega desenfreada às paixões, mas sim de libertar o homem desse sofrimento. Trata-se de mostrar a importância de reconhecer a verdadeira natureza do homem que é negada pelo artifício das regras impostas pela educação que, por meio da difusão da crença em Deus, em uma lei natural e em uma vida futura, impõe limites aos seus impulsos. É exatamente nessa negação que está situado o arbítrio das regras, nos limites impostos por elas que se encontra o conflito interno que leva ao sofrimento quando se dá vazão aos impulsos naturais, sobre os quais, não custa repetir, não se tem qualquer controle, como se fosse algo censurável. A ênfase está posta na injustiça das leis, pelo fato de apelar contra aqueles que não são criminosos culpáveis, posição já defendida em O homem-máquina. La Mettrie centra sua crítica na educação justamente pelo fato de ela visar a alterações internas, ao procurar impedir que o homem aceitese como é e siga sua natureza. É essa imposição vinda da formação do indivíduo, internalizada, que gera o sofrimento, e não as coerções externas, necessárias para o interesse 
geral, para a manutenção da sociedade. O resultado dessa coerção interna é o mal-estar que, na concepção de um médico, deve ser erradicado.

Em La Mettrie, o determinismo vinculado à força orgânica rege o funcionamento de nossos órgãos e, como é enfatizado desde o Tratado da alma, interfere nas operações mentais. Ao levar em conta esse determinismo, o autor reconhece a importância da educação na correção das inclinações que podem ser prejudiciais ao convívio social, mas destaca sua fragilidade perante aquela força de natureza fisiológica. Como já foi afirmado, a educação constitui-se como uma segunda qualidade do homem que necessita, como base, de uma boa estrutura orgânica para levar a bons resultados. Assim, a preponderância da constituição fisiológica em relação à educação, caracterizando a fragilidade desta última, pode ser entendida por meio do vínculo que o filósofo estabelece entre hábito e educação. A educação procura inculcar hábitos que inibam os instintos naturais, mas a tensão entre as duas instâncias permanece. Aquela força orgânica, por ser originária, prepondera, e a educação, ao deter ainda alguma força, faz que surja o sentimento de remorso que se constitui como produto do artifício que vai de encontro com o natural, gerando o mal-estar com as consequências danosas ao organismo. A preponderância da força orgânica em relação à educação, que se caracteriza como antinatural, está assentada no caráter permanente do que é natural em oposição à inconstância da educação, pois seus efeitos podem deixar de vigorar conforme a situação assim o exija; o artifício sempre será mais fraco do que aquilo que é instituído pela natureza, como é o caso da estrutura orgânica. O efeito da educação sobre a mente provoca alterações de forma que os instintos fiquem abafados e que se passe a seguir o oposto do que eles indicavam. Por meio da imagem do cata-vento, La Mettrie procura ilustrar a efemeridade da educação em relação às "disposições primitivas":

Verdadeiros cata-ventos, viramo-nos, então, sem cessar pelo vento da educação e retornamos, em seguida, ao nosso primeiro ponto, quando nossos órgãos, reconduzidos ao seu tom natural, tornam a nos fazer voltar a eles e fazem-nos seguir suas disposições primitivas. Então as antigas determinações renascem; aquelas que a arte produziu se apagam (La Mettrie, $1987 \mathrm{e}$, p. 264).

O homem seguir a sua natureza sem sofrer não implica ele deixar de seguir as leis da sociedade, uma vez que elas preservam o interesse geral e afetam também o bemestar individual. Mas como conciliar as duas esferas? Lembremos que o objetivo de La Mettrie, enquanto médico, está voltado para o bem-estar individual pautado no extravasamento dos impulsos. Uma boa organização, uma boa constituição, então, é requerida para atingir o objetivo que é a felicidade com o consequente bem-estar. Como afirma o próprio autor, ao satisfazer as necessidades, os impulsos do organismo, evita- 
mos as doenças mas, para isso, é preciso ser bem constituído para chegar a um bom resultado, qual seja, o bem-estar. Dessa forma, fica traçada uma demarcação entre os homens: os bem constituídos que têm condições de seguir sua natureza, sem ter remorsos, e os que não as têm. Essa diferença está na base da defesa de uma elite formada por aqueles cujas paixões não incitam ao crime, que podem dar vazão aos seus impulsos sem serem apenados pelo sentimento de remorso e preservam as regras de convivência.

Eu não ignoro que certos temperamentos fracos possam, ou melhor, devam se privar disso [da volúpia proveniente da satisfação dos impulsos orgânicos] para passarem bem e melhor gozarem outros prazeres; mas a volúpia conduzida de forma prudente constitui uma necessidade tão grande quanto as outras, e a natureza empregou os mesmos meios para provocá-la. Por essa razão, Celso, seu comentador Lommius, Venette, Boerhaave e todos os mais importantes filósofos e médicos não tiveram dificuldade em recomendá-la em seus escritos (La Mettrie, 1987e, p. 283).

A constatação de haver tantos indivíduos que apresentam conduta inadequada leva La Mettrie a procurar compreendê-los a partir da organização que não pode ser controlada. Por isso, não se trata de defesa do crime, mas sim de compreender a sua ocorrência ao buscar as causas na determinação biológica.

Eu não moralizo, não prego e tampouco invectivo; eu explico. Eu sou e tenho a honra de ser um cidadão zeloso, mas não é nessa condição que escrevo, e sim como filósofo. Como tal, vejo que Cartouche ${ }^{22}$ foi feito para ser Cartouche, como Pirro para ser Pirro; vejo que um foi feito para roubar e matar de forma pouco violenta e o outro com violência manifesta. Os conselhos são inúteis para quem nasce com sede de matança e de sangue (La Mettrie, 1987e, p. 287-8).

Como filósofo, procura compreender e explicar como se dão esses atos, mas como cidadão, ele preza a manutenção da ordem na sociedade, ainda que não concorde com os meios utilizados para tal, que encontram apoio no remorso difundido pela educação. Se a natureza dirige os atos e se todos somos determinados pelo sentimento de bem-estar, então devem ser consideradas as formas variadas de se atingir esse sentimento. É essa variedade que se encontra exposta no Anti-Sêneca e, no esforço de compreensão dos atos que propiciam o encontro com a felicidade, o autor chega a afirmar 
que há pessoas que a encontram em atos absolutamente hediondos e não devem ser punidas por isso. A defesa dessa posição foi alvo de críticas acirradas que não consideraram o seu contexto, a saber, a moralidade como produto da sociedade deve ser analisada dentro do âmbito de uma investigação científica que se situa fora do artificialismo. A filosofia unida à medicina apresenta as condições adequadas para esse exame, e o Discurso preliminar, de 1750, enfatiza não só a importância dessa união como torna mais precisa a sua defesa de uma moral da natureza.

Logo no início desse texto, encontra-se uma manifestação exaltada, bem ao estilo de La Mettrie, contra o encaminhamento adotado no tratamento de assuntos referentes à filosofia da natureza que adota a explicação teleológica e a defesa da providência divina:

Abri os olhos e vós vereis alardeados em todas as partes: provas da existência de Deus pelas maravilhas da natureza; provas da imortalidade da alma pela geometria e pela álgebra; a religião provada pelos fatos; teologia física (La Mettrie, 1987f, p. 9).

Livros com tais títulos ${ }^{23}$ levam a pensar que a filosofia vincula-se de tal forma à religião e à moral que o estudo da natureza poderá propiciar não só "o conhecimento de seu adorável autor como também a apreensão das verdades morais e reveladas" (La Mettrie, 1987f, p. 52). No Discurso preliminar, a cisão entre natural e artificial apresenta-se de forma mais acentuada a ponto de o autor se referir à moral da natureza, por ele defendida, em oposição a todos os artifícios forjados para o bem da sociedade, tais como a religião e a política, que se reúnem na constituição do que se conhece por moral. A moral da natureza identifica-se com a filosofia que, para o autor, deve estar voltada para os "fenômenos, causas, efeitos" e igualar-se à "ciência das coisas por seus efeitos", à ciência dos corpos, ou seja, à ciência da natureza (La Mettrie, 1987f, p. 11, 411). Ao estabelecer essa vinculação entre filosofia e ciência da natureza, La Mettrie aproxima a filosofia da medicina enfatizando o ponto em comum entre elas, o de só se voltar para o que pode estar pautado na observação e na experiência, afastando-se de qualquer fonte que ultrapasse os fenômenos da natureza, dentre os quais se situa o homem. Tal aproximação tem por fim, por um lado, ampliar o campo da medicina para além do tatear de um "cego empirismo" e promover uma aliança entre a experiência e a razão 
(cf. La Mettrie, 1987f, p. 35), de forma que esta se apóie sobre aquela; por outro lado, fortalecer a filosofia por meio do recurso à experiência, recusando a construção de hipóteses abstratas que não encontram sustentação na natureza, que é o seu campo de reflexão. Assim como o médico não deve se pautar unicamente pela experiência sem o auxílio da razão, a filosofia não se deve entregar aos devaneios da razão em suas incursões para além da experiência sensível. Por isso, La Mettrie afirma que, no estudo da natureza, é preciso descer das nuvens, ${ }^{24}$ que só oferecem um aparente conhecimento, pois estão distantes do objeto a ser conhecido, para chegar ao terreno da física no qual deve ser considerada a matéria organizada. Nesse contexto, não há conciliação entre a moral da natureza - a filosofia -, de um lado, e a moral como artifício, de outro; suas esferas de atuação estão separadas e uma não interfere no campo da outra. Na ênfase dessa separação, La Mettrie constrói a defesa da posição afirmada noAnti-Sêneca, com a finalidade de mostrar que acatar o determinismo biológico na base de nossas ações não constitui uma ameaça para a organização social e suas regras.

Natureza e sociedade são os pontos destacados por La Mettrie no Discurso preliminar. Enquanto a primeira é apresentada com aspectos favoráveis que levam ao bemestar, a segunda é caracterizada como calcada em preconceitos e erros que acabam impondo uma alteração no interior do homem, ou seja, em seus impulsos, que o levam à infelicidade e seu consequente mal-estar, como havia sido afirmado no texto anterior. A filosofia, do lado da natureza, analisa e critica a religião, as convenções sociais, mas não interfere nas relações de convívio social. Ela em nada interfere na sociedade por ser de natureza especulativa, suas hipóteses constituem-se como verdades ideais, a exemplo do que ocorre nas matemáticas (cf. La Mettrie, 1987f, p. 21). Além disso, essa ausência de interferência é afirmada com base no círculo restrito a que se restringe a filosofia; se é verdade, na visão lamettriana, que seus princípios não têm por objetivo e nem como objeto uma prática social, a política, isso não significa que eles destruam ou mesmo refutem os princípios sobre os quais se apóia a sociedade. Essa oposição e a ausência de intercâmbio entre as duas esferas possibilitam a crítica à moral, tal qual se observa no Anti-Sêneca e que é retomada no Discurso preliminar, uma vez que o interesse geral permanece inabalado por pertencer a outro âmbito que não à filosofia. Assim, a defesa do materialismo na explicação sobre o homem, com sua consequente rejeição de uma alma imortal e a afirmação de um determinismo orgânico, mostra-se igualmente inofensiva para a ordem social.

24. La Mettrie refere-se textualmente a uma máquina suspensa, utilizada na apresentação de óperas, particularmente na ópera barroca, circundada de raios luminosos e nuvens, na qual ficavam as divindades, máquina esta comparada ao que ele denominou "máquina teológica". 
Quem vive como cidadão pode escrever como filósofo. Mas escrever como filósofo é ensinar o materialismo! Que mal há nisso, se esse materialismo é fundamentado, se ele é o resultado evidente de todas as observações e experiências dos maiores filósofos e médicos? Se só aderimos a esse sistema depois de termos seguido atentamente a natureza, de termos feito os mesmos passos incessantemente com ela em toda a extensão do reino animal e, por assim dizer, depois de ter examinado a fundo o homem em todas as suas idades e em todos os seus estados? (La Mettrie, 1987f, p. 18).

A conclusão à qual chega o materialismo lamettriano - o homem é uma máquina - em nada perturba as relações de convivência, pois apenas poucos a aceitam, uma vez que, como afirma La Mettrie, “o povo jamais acreditará nisso" (La Mettrie, 1987f, p. 20). Os hábitos adquiridos ao longo de toda a formação e do convívio social acabam por reforçar a crença em princípios naturais que regem as ações humanas, dentre os quais se destaca o sentimento de remorso, de culpa, que acaba por gerar distúrbios mentais. Como o vulgo está distante da filosofia, não lê os livros de filosofia e, quando o faz, não chega a acreditar no que ali encontra, a filosofia não apresenta ameaça alguma. "Não temamos, então, que o espírito do povo se molde sobre o dos filósofos, muito acima de seu alcance" (La Mettrie, 1987f, p. 23).

Ao avaliar dessa maneira a capacidade do povo em assimilar o conteúdo filosófico, La Mettrie indica, com uma clareza que está ausente na obra anterior, a composição da casta à qual se dirige a filosofia. Àqueles que não têm o mínimo de "tintura filosófica", como afirma o autor, fica impossível compreender a maneira de ser de um físico que está habituado à reflexão. São categorias que nada têm em comum e "são duas fisionomias que jamais se assemelharão, dois instrumentos dos quais um é feito ao torno, cinzelado, trabalhado, o outro é bruto e tal qual saiu das mãos da natureza" (1987f, p. 23). Como as esferas do cidadão e do filósofo não têm um ponto de intersecção, é possível pensar como filósofo e agir como cidadão:

Qualquer que seja a minha especulação no repouso de meu gabinete, minha prática no mundo raramente se encontra com ela. Eu não moralizo nem verbalmente e nem por escrito. Em minha casa, escrevo o que me parece verdadeiro, na dos outros, eu digo o que me parece bom, salutar, útil e vantajoso (La Mettrie, 1987f, p. 32 ).

Nessa dissociação, La Mettrie assenta a impossibilidade de o filósofo interferir de forma a perturbar as convenções sociais, uma vez que ele está voltado para a interioridade, ou seja, para a manutenção do equilíbrio interno que gera o bem-estar, no 
qual é possível encontrar a felicidade. A alegada diferença entre o filósofo, identificado ao homem hábil, e o povo, tido como ignorante, enfatizada em várias passagens do texto, é como uma prega, uma marca feita nos homens, por meio do hábito, que torna muito difícil, senão impossível, uma troca entre eles. Afinal, os preconceitos estão como que arraigados no ignorante que só consegue repetir os "argumentos de nossas escolas e de nossos pedantes" (La Mettrie, 1987f, p. 23), ou seja, os teólogos, enquanto o homem hábil, ao seguir "passo a passo a natureza, a observação e a experiência" (La Mettrie, 1987f, p. 25), só dá seu assentimento pautando-se em alto grau de probabilidade e verossimilhança a partir de fatos que se apresentem com clareza, tendo como guia princípios bem fundados. Em outras palavras, o assentimento é dado com base na adoção de um método investigativo que deve primar pela objetividade. O filósofo, o homem hábil, então, encontra-se com o físico e com o médico na defesa dos procedimentos que são comuns às duas áreas. Essa demarcação defendida por La Mettrie prepara o terreno para a defesa da docilidade da filosofia, ou seja, da impossibilidade de a filosofia perturbar a ordem civil. O recurso utilizado pelo autor consiste em apontar as boas qualidades de um filósofo, tais como a imparcialidade, na recusa a pertencer a grupos, a sociabilidade, por observar as regras da sociedade, o que lhe possibilita cultivar os prazeres intelectuais e sensíveis sem exortar o crime e a desordem, e a autocrítica, expediente muito utilizado pelo próprio La Mettrie em suas obras. ${ }^{25}$ A possibilidade de dar vazão aos impulsos, ao cultivar os prazeres sensíveis, sem que isso o incline ao crime, indica que o filósofo ou o homem hábil, ou ainda, o homem virtuoso (honnête homme) deva ser bem constituído, pois a boa organização é a condição para seguir a natureza sem ter o sentimento de remorso e respeitar as convenções sociais, como foi defendido no Anti-Sêneca.

A separação entre a sociedade e a filosofia, além de indicar a ausência de periculosidade desta última em relação à primeira, serve para mostrar que a filosofia pode oferecer um auxílio ao bem público. Isso, porque, ao estar vinculada à natureza, ela reflete com distanciamento e isenção sobre os produtos do artifício, tais como as leis, a justiça e o bem moral. A filosofia procura esclarecer as ações dos governantes, dos magistrados, com o objetivo de evitar as injustiças, por isso La Mettrie chega a exortar que "aqueles que têm o timão do Estado sejam um pouco filósofos" (La Mettrie, 1987f, p. 42). Não se trata de fazer um trabalho de doutrinação do povo, pois o autor é bem claro quanto à impossibilidade de todos poderem compreender a filosofia, por questões de limitações naturais, orgânicas, tais como as que podem ser observadas no reino animal:

25 Neste trabalho apontamos dois exemplos de autocrítica que mostram a alteração ocorrida no pensamento de La Mettrie. No entanto, o recurso à autocrítica em outras obras serve para reforçar a posição criticada em tom irônico. Como um exemplo deste último caso, podemos citar Os animais mais que máquinas. 
Eu não pretendo insinuar com isso que se devam empreender todos os esforços para doutrinar o povo e admiti-lo nos mistérios da natureza. Percebo muito bem que a tartaruga não pode correr, os animais que rastejam não podem voar, nem os cegos ver (La Mettrie, 1987f, p. 42).

As novas verdades às quais a filosofia chega, afastando-se de teorias que defendam a imortalidade da alma, que exponham provas da existência de Deus e que se pautem no misticismo, só engrandecem o espírito daqueles que a cultivam. Essas verdades, porém, nem sempre são bem recebidas, a exemplo do que ocorre com o materialismo lamettriano que encontra resistência por parte dos próprios filósofos. Para mencionar apenas dois: Voltaire critica o extremo ao qual chegou La Mettrie em seu combate às superstições e que o levou a defender um rompimento com a sociedade e suas leis, chegando a qualificá-lo como louco; D’Holbach desqualifica as reflexões de La Mettrie sobre moral como consequências de um delírio. A defesa que La Mettrie faz da filosofia no Discurso preliminar constitui-se como uma autodefesa perante as críticas recebidas pela publicação de $O$ homem-máquina e do Anti-Sêneca, para nos limitarmos apenas a duas obras citadas nesse Discurso. A divulgação, sem restrição, dos resultados da reflexão filosófica é defendida como um benefício público, uma vez que aguça e amplia o espírito do leitor, levando a novos conhecimentos. Ainda que haja erros, essa utilidade não diminui, pois a partir deles outras verdades poderão surgir, como foi o caso das falsas hipóteses de Descartes, “que são tidas como felizes erros, pelo fato de elas terem possibilitado a previsão e descoberta de muitas das verdades que estariam ainda desconhecidas sem elas" (La Mettrie, 1987f, p. 4, $)$ ). A filosofia segue adiante; a partir dos erros exercita o espírito e amplia a capacidade de abarcar cada vez mais objetos, o que possibilitará uma nova visão sobre questões referentes à sociedade, com a finalidade de promover um tratamento mais equânime e justo por parte dos governantes. $\mathrm{O}$ filósofo, com o espírito fortalecido dessa maneira, terá condições de propor novas soluções a problemas detectados no âmbito da sociedade, diagnosticar abusos cometidos e encontrar formas mais eficazes de "remediar a desordem". É dessa forma que a filosofia tem condições de ser útil, e o filósofo assume uma função social. Conduzir os homens "pelas luzes naturais da razão" traz benefício direto a todos, pois só assim será possível promover a paz e propiciar uma harmoniosa convivência social. A partir da compreensão de que a filosofia e a autonomia de pensamento não são perigosas para a sociedade, os governantes poderão enxergar os benefícios de sua expansão sobre o aperfeiçoamento da espécie humana por meio do combate aos preconceitos e o consequente melhoramento nas relações sociais, fundando uma sociedade mais justa e equilibrada (cf. La Mettrie, 1987f, p. 41). 
A conciliação entre a afirmação segundo a qual a filosofia não apresenta perigo à sociedade, por se situar em outra esfera, e a utilidade da filosofia, que se mostra por meio da influência por ela exercida ao longo do tempo, possibilitando mesmo um aperfeiçoamento da espécie humana, ocorre por meio da moral da natureza, a única moral que faz parte da filosofia, segundo a concepção lamettriana. Essa moral deve ser compreendida como um estudo do comportamento humano sob o ponto de vista psicofisiológico, como é possível inferir da leitura dos textos mencionados neste trabalho. Neles encontramos a constante referência à influência que a máquina corpórea, com suas funções, exerce sobre a mente, provocando alterações comportamentais que podem levar a atos inusitados e, até mesmo, criminosos. Nessa esfera, a importância do médico fica patente, uma vez que só ele, por sua especialidade, tem condições para diagnosticar o quadro patológico, de forma a atacar a causa e restituir o equilíbrio físico e mental. Essa visão clínica da moral mostra-se na avaliação médica das causas que levam a ações condenáveis e estão associadas a doenças mentais (cf. La Mettrie, 1987d, p. 68-9), além da defesa da felicidade orgânica associada ao bem-estar.

\section{COMENTÁRIO FINAL}

Voltar-se para o homem em todas as suas idades e em todos os seus estados é a recomendação básica defendida por La Mettrie para construir uma filosofia que seja consequente e que se afaste dos devaneios engendrados pela pretensão metafísica em defender a imortalidade da alma. Na defesa do materialismo encontrada no Discurso preliminar, La Mettrie assenta a sua filosofia. E adotar o materialismo como lema filosófico significa privilegiar a ciência pautada nos fenômenos como pedra fundamental para a construção do conhecimento, tomando como modelo a medicina. A medicina é colocada em relevo pelo médico-filósofo, pois só ela mostra a materialidade e a mortalidade do homem. Ser versado em física, o que significa conhecer a mecânica do corpo, como ele mesmo afirma, sem considerar assuntos vãos, tais como os que se voltam para a alma, constitui o primeiro passo para a elaboração científica. Tal importância da ciência médica aponta para um fim que se mostra carregado de valor moral, pois ao visar à saúde do corpo, a medicina propicia a boa formação do espírito, por "elevá-lo ao conhecimento da verdade e da virtude", como é afirmado em 0 homem-máquina. Mas a moral defendida por La Mettrie está vinculada à sua prática médica, uma vez que ela leva em consideração a organização do corpo e a influência que ela exerce sobre a mente, quando há algum distúrbio nos órgãos, além de considerar o determinismo biológico que leva o homem a cometer atos que podem ser condenáveis. Cabe ao filó- 
sofo compreender e esclarecer como se dão esses atos, antes de qualquer valoração, pois eles podem ser consequência de algum desarranjo orgânico e necessitarem de um tratamento no lugar de uma punição. Afinal, é preciso considerar antes as leis da natureza às quais as leis humanas deveriam se submeter. Essa visão lamettriana acaba por caracterizar a moral como um estudo do comportamento humano, que se pauta nos aspectos fisiológicos e psicológicos, e como um problema médico, constituindo-a como uma moral da natureza, em clara oposição à moral como artifício que visa à manutenção da ordem social em detrimento das considerações sobre a natureza orgânica do homem.

A postura adotada por La Mettrie constitui-se como a defesa do "puro naturalismo", como o autor se refere ao modo de proceder adequado a um médico:

Entre dois médicos, o melhor, aquele que merece mais confiança é sempre, do meu ponto de vista, aquele que é o mais versado em física ou mecânica do corpo humano e que, ao deixar a alma e todas as inquietudes que essa quimera provoca nos tolos e nos ignorantes, volta-se seriamente para o puro naturalismo (1987d, p. 110).

Esse naturalismo, herança de sua formação médica, está expresso em várias passagens de sua obra, tais como a afirmação da dependência da alma em relação ao corpo, da impossibilidade de demonstração da imortalidade da alma e da existência de Deus, por ultrapassarem os limites da experiência sobre a qual pautamos o nosso conhecimento, do imanentismo e da inutilidade da crença na recompensa após a morte. Nesse posicionamento, as determinações orgânicas, a necessidade de dar vazão aos impulsos e a valorização dos instintos levam à defesa de uma moral que se apresenta como um prolongamento da medicina, na busca da felicidade que coincide com o bem-estar, com a saúde. A originalidade de La Mettrie situa-se ao aproximar a filosofia da ciência, dando origem ao materialismo médico. Assim, a filosofia fica atrelada ao conhecimento do corpo humano, de forma que o ponto de partida situa-se na observação cuidadosa do corpo, e a introspecção apresenta-se de forma bastante específica na importância da consideração do interior do organismo, para chegar à constituição de um conhecimento que se mostre bem fundamentado. O conhecimento das partes do corpo, bem como das leis que regem o funcionamento dessas partes, é fundamental para evitar os paradoxos em que se pode cair quando ocorre o distanciamento do campo da experiência e da observação. Com essa postura, La Mettrie atrela à ciência um valor moral, pois o aperfeiçoamento da inteligência e do caráter, que estão vinculados à organização, reflete sobre o corpo com o qual a mente mantém uma relação de dependência. Essa dependência indica que a saúde do corpo reflete sobre a saúde mental e, por consequência, as ações devem ser compreendidas nessa relação. Dessa maneira, o bem 
e o mal ficam diluídos na boa ou na má organização que está na base do fatalismo lamettriano, segundo o qual nascemos com propensão invencível ao próprio bem, de modo que o homem acaba por tornar-se cativo de sua organização.@

\author{
Marisa Carneiro De Oliveira Frango Donatelli \\ Universidade Estadual de Santa Cruz, \\ Ilhéus, Bahia, Brasil. \\ madonat@uesc.br
}

\title{
Philosophy and medicine in La Mettrie
}

\begin{abstract}
To La Mettrie, the study of nature begins in the man whose structure should be considered in comparison with that of animals, all being subjected to the same laws, and subject to destruction. By adopting the medical point of view, La Mettrie brings close philosophy and medicine. Following this approach, this paper aims to address how the close connection between philosophy and medicine is possible, by emphasizing the entanglement between medical, philosophical and moral points of views.
\end{abstract}

KeYwords • Materialism. Organization. Remorse. Nature's moral.

\section{REFERÊNGIAS BIBLIOGRÁFICAS}

Adam, C. \& Tannery, P. Euvres de Descartes. Paris: Vrin/Centre National du Livre, 1996. 11 v. (AT).

Audidiène, S. Matérialistes français du ХVIIIe siècle. La Mettrie, Helvétius, d'Holbach. Paris: PUF, 2006.

Guichet, J. L. Del'animal-machine à l'âme des machines: querelles biomécaniques de l'âme (XVIIe-XVIIIe siècle).

Paris: Publications de la Sorbonne, 2010.

La Mettrie, J. O. L'homme-machine. Paris: Denoël, 1981.

. Traité du vertige. Paris: Fayard, 1987 a.

. Traité de l'âme. Paris: Fayard, $1987 \mathrm{~b}$.

. Abrégé des systèmes. Paris: Fayard, $1987 \mathrm{c}$.

. L'homme-machine. Paris: Fayard, $1987 \mathrm{~d}$.

. Anti-Seneque ou discours sur le bonheur. Paris: Fayard, 1987e.

. Discours préliminaire. Paris: Fayard, $1987 \mathrm{f}$.

Lettre critique à madame la Marquise du Châtelet, 1747 . Corpus Revue de Philosophie, 5, 6, p. 14.3-8,

1999.

. L'homme-plante. Paris: Le Corridor Bleu, 2003.

LANGe, F. A. Histoire du materialism. Paris: Coda, 2004.

Morilhat, C. La Mettrie. Un matérialiste radical. Paris: PUF, 1997.

Thomson, A. Materialism and society in the mid-eighteenth century: La Mettrie's Discours préliminaire. Genève: Librairie Droz, 1981.

Vartanian, A. La Mettrie's L'homme machine: a study in the origins of an idea. Princeton: Princeton University Press, 1960.

. Science and humanism in the french enlightenment. Charlottesville: Rookwood Press, 1999. 